\title{
Synthesis, Crystal Structure and Thermal Decomposition Mechanism of a Samarium $o$-Chlorobenzoate Complex with 1,10-Phenanthroline
}

\author{
Jian-Jun Zhang, ${ }^{*, a}$ Ning Ren, ${ }^{a, b}$ Yan-Xun Wang, ${ }^{c}$ Su-Ling Xu, ${ }^{a, b}$ Rui-Fen Wang ${ }^{b}$ and Shu-Ping Wang ${ }^{b}$ \\ ${ }^{a}$ Experimental Center, Hebei Normal University, Shijiazhuang, 050016, P. R.China \\ ${ }^{b}$ College of Chemistry \& Material Science, Hebei Normal University, Shijiazhuang, 050016, P. R. China \\ ${ }^{c}$ Hebei Institute of Architectural and Civil Engineering, Zhangjiakou, 075024, P. R. China
}

$\mathrm{O}$ complexo $\left[\mathrm{Sm}(\mathrm{o}-\mathrm{ClBA})_{3} \text { phen }\right]_{2}(\mathrm{o}-\mathrm{ClBA}=\mathrm{o}$-clorobenzoato; phen $=1,10$-fenantrolina $)$ foi preparado pela reação de $\mathrm{SmCl}_{3} \cdot 6 \mathrm{H}_{2} \mathrm{O}$ com ácido o-clorobenzóico e 1,10-fenantrolina. O complexo foi caracterizado por um estudo de difração de raios-X, análise elementar, espectroscopia no infravermelho e técnicas TG-DTG. O cristal é triclínico, grupo espacial $P$ I com $a=13,157(3) \AA, b=14,139(4) \AA, c=17,397(4) \AA, \alpha=83,755(3)^{\circ}, \beta=84,064(3)^{\circ}$, $\gamma=73,434(3)^{\circ}, Z=2, D c=1,722 \mathrm{Mg} / \mathrm{m}^{3}, F(000)=1572$. Contém duas unidades cristalograficamente distintas de $\mathrm{Sm}\left(\mathrm{o}-\mathrm{ClC}_{6} \mathrm{H}_{4} \mathrm{COO}\right)_{3}\left(\mathrm{C}_{12} \mathrm{H}_{8} \mathrm{~N}_{2}\right)$, formando dois tipos de moléculas binucleares. Cada $\mathrm{Sm}^{3+}$ encontra-se coordenado a dois átomos de oxigênio de um grupo carboxilato bidentado quelante, cinco átomos de oxigênio de dois grupos carboxilatos bidentados ligados em ponte e de três grupos carboxilatos tridentados quelantes e ligados em ponte, e a dois átomos de nitrogênio de uma molécula de 1,10-fenantrolina, completando uma geometria monoencampuzada antiprismática quadrada. A decomposição térmica deste composto foi estudada por técnicas TG-DTG, e os parâmetros cinéticos da primeira etapa da decomposição foram determinados pelos métodos de Kissinger e Ozawa-Doyle. A equação de meia vida após 10\% de perda de peso, $\ln \tau=-26,8166+20319,94 / T$, foi deduzida por análise termogravimétrica da isoterma.

The title complex $\left[\mathrm{Sm}(\mathrm{o}-\mathrm{ClBA})_{3} \text { phen }\right]_{2}(\mathrm{o}-\mathrm{ClBA}=\mathrm{o}$-chlorobenzoate; phen $=1,10$ phenanthroline) was prepared by the reaction of $\mathrm{SmCl}_{3} \cdot 6 \mathrm{H}_{2} \mathrm{O}$, o-chlorobenzoic acid and 1,10 phenanthroline. The complex was characterized by single crystal X-ray diffraction, elemental analysis, IR spectra and TG-DTG techniques. The results show that the crystal is triclinic, space group $P \overline{\mathrm{I}}$ with $a=13.157(3) \AA, b=14.139(4) \AA, c=17.397(4) \AA, \alpha=83.755(3)^{\circ}, \beta=84.064(3)^{\circ}$, $\gamma=73.434(3)^{\circ}, Z=2, D c=1.722 \mathrm{Mg} / \mathrm{m}^{3}, F(000)=1572$. The crystal contains two crystallographically distinct $\mathrm{Sm}\left(\mathrm{o}-\mathrm{ClC}_{6} \mathrm{H}_{4} \mathrm{COO}\right)_{3}\left(\mathrm{C}_{12} \mathrm{H}_{8} \mathrm{~N}_{2}\right)$ units, forming two types of binuclear molecule. Each $\mathrm{Sm}^{3+}$ is coordinated to two $\mathrm{O}$ atoms of one bidentate chelating carboxylate group, five $\mathrm{O}$ atoms of two bidentate bridging and two tridentate chelating-bridging carboxylate groups, and two $\mathrm{N}$ atoms of one 1,10-phenanthroline molecule to complete a distorted mono-capped square antiprism geometry. Its thermal decomposition mechanism was determined by TG-DTG techniques, and kinetic parameters have been studied on the first-step decomposition of $\left[\operatorname{Sm}(\mathrm{o}-\mathrm{ClBA})_{3} \text { phen }\right]_{2}$ by means of Kissinger's method and Ozawa-Doyle's method. The lifetime equation at weight-loss of $10 \%$ was deduced as $\ln \tau=-26.8166+20319.94 / T$ by isothermal thermogravimetric analysis.

Keywords: $o$-chlorobenzoic acid, crystal structure, 1,10-phenanthroline, samarium complex, thermal decomposition kinetics

\section{Introduction}

The coordination chemistry of rare-earth cations with various carboxylic acids has become increasingly significant in the recent years, due to the potential applications in many areas, such as extraction, separation, germicide preparation,

*e-mail: jjzhang6@sohu.com catalysis, luminescence and functional material preparation. ${ }^{1}$ Perhaps, the most important feature of the rare-earth carboxylate complexes is the large number of coordination types exhibited by these ligands, e.g, bidentate chelating, bidentate bridging or tridentate chelatingbridging. ${ }^{2}$ For this reason there has been continuing interest in the study of such complexes. In previous work,,$^{3-15}$ we reported the synthesis, crystal structure and thermal 
decomposition behavior of a number of europium or terbium complexes with benzoic acid or its derivatives and 1,10phenanthroline. In this work, we describe the synthesis and crystal structure, of the title complex, determined by a single crystal X-ray diffraction study. We also discuss a mechanism for the thermal decomposition, studied by TG-DTG techniques, from which we obtained the activation energy $E$ and the pre-exponential factor $A$ using Kissinger's method $^{16}$ and Ozawa-Doyle's method. ${ }^{17-18}$

\section{Results and Discussion}

\section{Infrared spectra}

The free acid COOH group band at $1693 \mathrm{~cm}^{-1}$, completely disappears in the spectra of the complex. However, the bands arising from asymmetric and symmetric vibrations of the $\mathrm{COO}^{-}$group occur at $1591 \mathrm{~cm}^{-1}, 1545 \mathrm{~cm}^{-1}, 1519 \mathrm{~cm}^{-1}$ and $1477 \mathrm{~cm}^{-1}, 1403 \mathrm{~cm}^{-1}, 1350 \mathrm{~cm}^{-1}$, respectively. This indicated that the carboxyl groups are bonded to Sm(III) ion in three coordination modes, ${ }^{19}$ which was confirmed by X-ray diffraction analysis. In addition, the bands of $\mathrm{v}_{\mathrm{C}=\mathrm{N}}(1646$ $\left.\mathrm{cm}^{-1}\right)$ and $\delta_{\mathrm{C}-\mathrm{H}}\left(854 \mathrm{~cm}^{-1}, 740 \mathrm{~cm}^{-1}\right)$ attributed to $1,10-$ phenanthroline are observed to move lower wave numbers at $1617 \mathrm{~cm}^{-1}, 852 \mathrm{~cm}^{-1}$ and $730 \mathrm{~cm}^{-1}$, respectively. This indicated that the $\mathrm{Sm}^{3+}$ ions were coordinated by the nitrogen atoms of the 1,10-phenanthroline. ${ }^{20}$

Table 1. Crystallographic data and structure refinement for $[\mathrm{Sm}(o-$ (lBA) ${ }_{3}$ phen $]_{2}$

\begin{tabular}{ll}
\hline Empirical formula & $\mathrm{C}_{66} \mathrm{H}_{40} \mathrm{Cl}_{6} \mathrm{~N}_{4} \mathrm{O}_{12} \mathrm{Sm}_{2}$ \\
Formula weight & 1594.42 \\
Temperature & $293(2) \mathrm{K}$ \\
Wavelength & $0.71073 \AA$ \\
Crystal system, space group & Triclinic, $P \hat{\mathrm{i}}$ \\
Unit cell dimensions & $\mathrm{a}=13.157(3) \AA \alpha=83.755(3)^{\circ}$ \\
& $\mathrm{b}=14.139(4) \AA \beta=84.064(3)^{\circ}$ \\
& $\mathrm{c}=17.397(4) \AA \gamma=73.434(3)^{\circ}$ \\
Volume & $3074.8(13) \AA^{3}$ \\
Z, Calculated density & $2,1.722 \mathrm{Mg} \mathrm{m}^{-3}$ \\
Absorption coefficient & $2.219 \mathrm{~mm}^{-1}$ \\
F(000) & 1572 \\
Crystal size & $0.38 \times 0.30 \times 0.22 \mathrm{~mm}$ \\
Theta range for data collection & 1.84 to $25.03^{\circ}$ \\
Limiting indices & $-15 \leq \mathrm{h} \leq 15,-16 \leq \mathrm{k} \leq 16$, \\
& $-20 \leq 1 \leq 12$ \\
Reflections collected / unique & $16702 / 10701\left[\mathrm{R}_{\text {(int) }}=0.0172\right]$ \\
Completeness to $\theta=25.03$ & $98.4 \%$ \\
Absorption correction & Semi-empirical from equivalents \\
Max. and min. transmission & 1.000000 and 0.648886 \\
Refinement method & Full-matrix least-squares on $F^{2}$ \\
Data / restraints / parameters & $10701 / 2 / 820$ \\
Goodness-of-fit on $F^{2}$ & 1.091 \\
Final $R$ indices [I $2 \sigma(\mathrm{I})]$ & $R 1=0.0326, w R 2=0.0901$ \\
$R$ indices (all data) & $R 1=0.0454, w R 2=0.0958$ \\
Largest diff. peak and hole & 0.906 and -0.731 e. $\AA$-3 \\
\hline
\end{tabular}

\section{Crystal structure}

Selected bond lengths and angles are listed in Table 2. The crystal is composed of two types of binuclear molecules, which are identical in composition with similar structures, as shown in Figure 1(a) and (b). In each binuclear molecule, two $\mathrm{Sm}\left(o-\mathrm{ClC}_{6} \mathrm{H}_{4} \mathrm{COO}\right)_{3}\left(\mathrm{C}_{12} \mathrm{H}_{8} \mathrm{~N}_{2}\right)$ units are combined through crystallographic inversion center. Each $\mathrm{Sm}^{3+}$ ion is coordinated to nine atoms, of which five atoms are from the bidentate bridging and tridentate chelating-bridging carboxylate groups, two oxygen atoms are from bidentate chelating carboxylate groups and two nitrogen atoms are from a 1,10phenanthroline molecule. The coordination polyhedron of Sm(III) ion adopts a distorted mono-capped square antiprism geometry. The oxygen atom from the tridentate chelating-bridging carboxylate group is at the capped position. The Sm-Sm distance in the molecule (a)(4.047
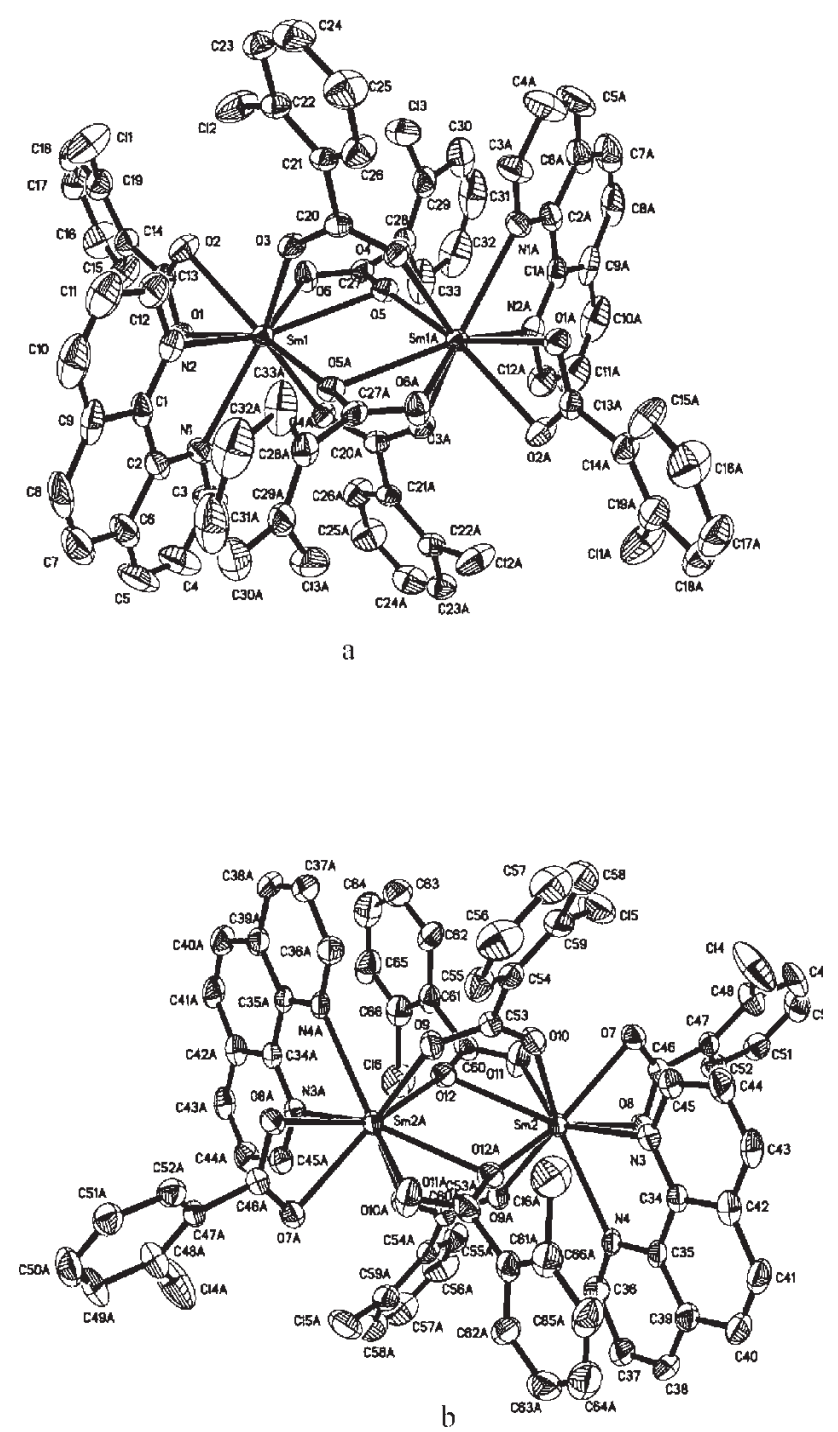

Figure 1. (a) and (b) Molecular structure of $\left[\operatorname{Sm}(o-\mathrm{ClBA})_{3} \text { phen }\right]_{2}$. 
Table 2. Selected bond lengths $(\AA)$ and angles $\left({ }^{\circ}\right)$ for the molecules (a) and (b)

\begin{tabular}{|c|c|c|c|}
\hline Sm1-O3 & $2.350(3)$ & $\mathrm{Sm} 2-\mathrm{O} 12^{\mathrm{a}}$ & $2.345(3)$ \\
\hline Sm1-O5 ${ }^{a}$ & $2.379(3)$ & Sm2-O10 & $2.377(4)$ \\
\hline $\mathrm{Sm} 1-\mathrm{O} 4^{\mathrm{a}}$ & $2.395(3)$ & $\mathrm{Sm} 2-09^{\mathrm{a}}$ & $2.381(4)$ \\
\hline $\mathrm{Sm} 1-\mathrm{O} 2$ & $2.433(4)$ & $\mathrm{Sm} 2-\mathrm{O} 8$ & $2.439(4)$ \\
\hline Sm1-O6 & $2.479(4)$ & Sm2-O11 & $2.482(4)$ \\
\hline Sm1-O1 & $2.487(3)$ & $\mathrm{Sm} 2-\mathrm{O} 7$ & $2.484(4)$ \\
\hline Sm1-N2 & $2.598(5)$ & $\mathrm{Sm} 2-\mathrm{N} 3$ & $2.604(4)$ \\
\hline Sm1-N1 & $2.609(4)$ & Sm2-N4 & $2.675(4)$ \\
\hline Sm1-O5 & $2.728(4)$ & Sm2-O12 & $2.695(4)$ \\
\hline $\mathrm{Sm} 1-\mathrm{Sm} 1^{\mathrm{a}}$ & $4.047(9)$ & $\mathrm{Sm} 2-\mathrm{Sm} 2^{\mathrm{b}}$ & $4.016(10)$ \\
\hline O3-Sm1-O5 ${ }^{\mathrm{a}}$ & $74.06(12)$ & $\mathrm{O} 12^{\mathrm{b}}-\mathrm{Sm} 2-\mathrm{O} 10$ & $73.25(13)$ \\
\hline $\mathrm{O} 3-\mathrm{Sm} 1-\mathrm{O} 4^{\mathrm{a}}$ & $133.62(12)$ & $\mathrm{O} 12^{\mathrm{b}}-\mathrm{Sm} 2-\mathrm{O} 9^{\mathrm{b}}$ & $77.06(12)$ \\
\hline $\mathrm{O}^{\mathrm{a}}-\mathrm{Sm} 1-\mathrm{O} 4^{\mathrm{a}}$ & $76.71(12)$ & O10-Sm2-O9b & $134.56(12)$ \\
\hline O3-Sm1-O2 & $75.85(12)$ & $\mathrm{O} 12^{\mathrm{b}}-\mathrm{Sm} 2-\mathrm{O} 8$ & $152.30(13)$ \\
\hline $\mathrm{O}^{\mathrm{a}}-\mathrm{Sm} 1-\mathrm{O} 2$ & $144.77(12)$ & O10-Sm2-O8 & $127.13(12)$ \\
\hline $\mathrm{O} 4^{\mathrm{a}}-\mathrm{Sm} 1-\mathrm{O} 2$ & $138.39(13)$ & $\mathrm{O} 9^{\mathrm{b}}-\mathrm{Sm} 2-\mathrm{O} 8$ & $93.90(12)$ \\
\hline O3-Sm1-O6 & $92.09(14)$ & $\mathrm{O} 12^{\mathrm{b}}-\mathrm{Sm} 2-\mathrm{O} 11$ & $123.16(13)$ \\
\hline $\mathrm{O}^{\mathrm{a}}-\mathrm{Sm} 1-\mathrm{O} 6$ & $123.80(12)$ & O10-Sm2-O11 & $91.38(17)$ \\
\hline $\mathrm{O} 4^{\mathrm{a}}-\mathrm{Sm} 1-\mathrm{O} 6$ & $75.38(14)$ & $\mathrm{O}^{\mathrm{b}}-\mathrm{Sm} 2-\mathrm{O} 11$ & $76.99(16)$ \\
\hline O2-Sm1-O6 & $74.92(14)$ & O8-Sm2-O11 & $78.76(14)$ \\
\hline O3-Sm1-O1 & $128.04(12)$ & $\mathrm{O} 12^{\mathrm{b}}-\mathrm{Sm} 2-\mathrm{O}(7)$ & $145.08(13)$ \\
\hline $\mathrm{O}^{\mathrm{a}}-\mathrm{Sm} 1-\mathrm{O} 1$ & $154.56(12)$ & $\mathrm{O} 10-\mathrm{Sm} 2-\mathrm{O} 7$ & $74.86(13)$ \\
\hline $\mathrm{O} 4^{\mathrm{a}}-\mathrm{Sm} 1-\mathrm{O} 1$ & $91.17(12)$ & $\mathrm{O} 9^{\mathrm{b}}-\mathrm{Sm} 2-\mathrm{O} 7$ & $137.13(13)$ \\
\hline O2-Sm1-O1 & $52.34(12)$ & $\mathrm{O} 8-\mathrm{Sm} 2-\mathrm{O} 7$ & $52.67(12)$ \\
\hline O6-Sm1-O1 & $72.79(12)$ & $\mathrm{O} 11-\mathrm{Sm} 2-\mathrm{O} 7$ & $71.16(14)$ \\
\hline O3-Sm1-N2 & $75.88(15)$ & $\mathrm{O} 12^{\mathrm{b}}-\mathrm{Sm} 2-\mathrm{N} 3$ & $84.27(13)$ \\
\hline $\mathrm{O}^{\mathrm{a}}-\mathrm{Sm} 1-\mathrm{N} 2$ & $80.46(13)$ & $\mathrm{O} 10-\mathrm{Sm} 2-\mathrm{N} 3$ & $75.02(14)$ \\
\hline $\mathrm{O} 4^{\mathrm{a}}-\mathrm{Sm} 1-\mathrm{N} 2$ & $132.90(15)$ & $\mathrm{O} 9^{\mathrm{b}}-\mathrm{Sm} 2-\mathrm{N} 3$ & $134.98(14)$ \\
\hline O2-Sm1-N2 & $74.78(15)$ & O8-Sm2-N3 & $84.06(14)$ \\
\hline O6-Sm1-N2 & $149.31(14)$ & $\mathrm{O} 11-\mathrm{Sm} 2-\mathrm{N} 3$ & $144.91(15)$ \\
\hline O1-Sm1-N2 & $92.33(14)$ & $\mathrm{O} 7-\mathrm{Sm} 2-\mathrm{N} 3$ & $74.06(14)$ \\
\hline O3-Sm1-N1 & $133.62(14)$ & $\mathrm{O} 12^{\mathrm{b}}-\mathrm{Sm} 2-\mathrm{N} 4$ & $77.42(13)$ \\
\hline $\mathrm{O}^{\mathrm{a}}-\mathrm{Sm} 1-\mathrm{N} 1$ & $80.18(12)$ & O10-Sm2-N4 & $129.74(14)$ \\
\hline $\mathrm{O} 4^{\mathrm{a}}-\mathrm{Sm} 1-\mathrm{N} 1$ & $73.66(14)$ & $\mathrm{O}^{\mathrm{b}}-\mathrm{Sm} 2-\mathrm{N} 4$ & $73.92(13)$ \\
\hline O2-Sm1-N1 & $108.79(14)$ & O8-Sm2-N4 & $74.92(13)$ \\
\hline O6-Sm1-N1 & $134.18(14)$ & O11-Sm2-N4 & $138.87(16)$ \\
\hline O1-Sm1-N1 & $74.93(13)$ & O7-Sm2-N4 & $113.88(12)$ \\
\hline N2-Sm1-N1 & $62.12(15)$ & N3-Sm2-N4 & $62.09(14)$ \\
\hline O3-Sm1-O5 & $68.52(12)$ & $\mathrm{O} 12^{\mathrm{b}}-\mathrm{Sm} 2-\mathrm{O} 12$ & $74.57(13)$ \\
\hline
\end{tabular}

${ }^{\mathrm{a}}-\mathrm{x}+1,-\mathrm{y}+2,-\mathrm{z}+1,{ }^{\mathrm{b}}-\mathrm{x}+2,-\mathrm{y}+1,-\mathrm{z}$

$\AA$ ) is longer than that in (b)(4.016 $\AA$ ). In the binuclear molecule (a), the $\mathrm{Sm}-\mathrm{O}$ distance is in a range of 2.350(3)$2.487(3) \AA$. The mean distance is $2.421 \AA$. The average of $\mathrm{Sm}-\mathrm{N}$ bond is $2.604 \AA$. In the binuclear molecule (b), the Sm-O bond length is in a range of 2.345(3) $-2.484(4) \AA$, with an average of $2.418 \AA$. The mean bond length of $\mathrm{Sm}-\mathrm{N}$ is $2.639 \AA$. The structure of this compound is similar to that of the analogous complex [Sm $(o-\mathrm{MBA})_{3}$ phen $]_{2}(o-$ $\mathrm{MBA}=o$-methylbenzoate),${ }^{13}$ in that they both consist of two similar types of binuclear molecules. However the average $\mathrm{Sm}-\mathrm{O}$ and $\mathrm{Sm}-\mathrm{N}$ distances in the later complex are slightly longer than those in $\left[\mathrm{Sm}(o-\mathrm{ClBA})_{3} \mathrm{phen}\right]_{2}$. The reason may be that the methyl is electron-donation group, while the chlorin is electron-withdraw group, which result in the enhancement of electron cloud density and the strength of the chemical bond.
In both binuclear molecules (a) and (b), the $\mathrm{Sm}-\mathrm{O}$ bond distances of the chelating carboxylate are longer than those of the bridging carboxylates groups, which clearly shows that the coordination of $\mathrm{Sm}^{3+}$ ion with the chelating carboxylate is weaker than that of $\mathrm{Sm}^{3+}$ ion with the bridging carboxylates groups, or rather that the formation of fourmembered chelate ring with $\mathrm{Sm}^{3+}$ ion is unstable. ${ }^{21}$

\section{Thermal decomposition mechanism}

The TG-DTG curves of the title complex at a heating rate of $5{ }^{\circ} \mathrm{C} \mathrm{min}-1$ under a nitrogen atmosphere are shown in Figure 2. The DTG curve reveals three decomposition stages. The first stage starts at $279.55^{\circ} \mathrm{C}$ and completes at $428.62{ }^{\circ} \mathrm{C}$ with a loss of $22.16 \%$ (theoretical loss is $22.60 \%$ ), corresponding to the remove of $2 \mathrm{~mol}$ phen. The bond distance of the structure of the complex can demonstrate the degradation. Average bond length of Sm$\mathrm{N}$ is longer than that of Sm-O, theoretically, Sm-N bond is less stable and easy to be broken down. The IR spectra of the residue at $428.62{ }^{\circ} \mathrm{C}$ also shows the disappearance of the absorption band of $\mathrm{C}=\mathrm{N}$ at $1617 \mathrm{~cm}^{-1}$.

The loss of the $o$-chlorobenzoate ligands occurs from 428.62 to $888.50{ }^{\circ} \mathrm{C}$ in two steps. The total weight loss is $54.80 \%$ (theoretical loss is $55.50 \%$ ). Up to $888.50{ }^{\circ} \mathrm{C}$, the title complex was completely degraded into $\mathrm{Sm}_{2} \mathrm{O}_{3}$ (observed, 22.09\%; calculated, 21.87\%), which was demonstrated by the IR spectra of the residue at 888.50 ${ }^{\circ} \mathrm{C}$. The bands of $\mathrm{v}_{\mathrm{as}(\mathrm{COO})}\left(1580-1546 \mathrm{~cm}^{-1}\right)$ and $\mathrm{v}_{\mathrm{s}(\mathrm{COO})}$ $\left(1479-1408 \mathrm{~cm}^{-1}\right)$ disappeared, and the IR spectra of the residue were same to standard spectra of $\mathrm{Sm}_{2} \mathrm{O}_{3}$.

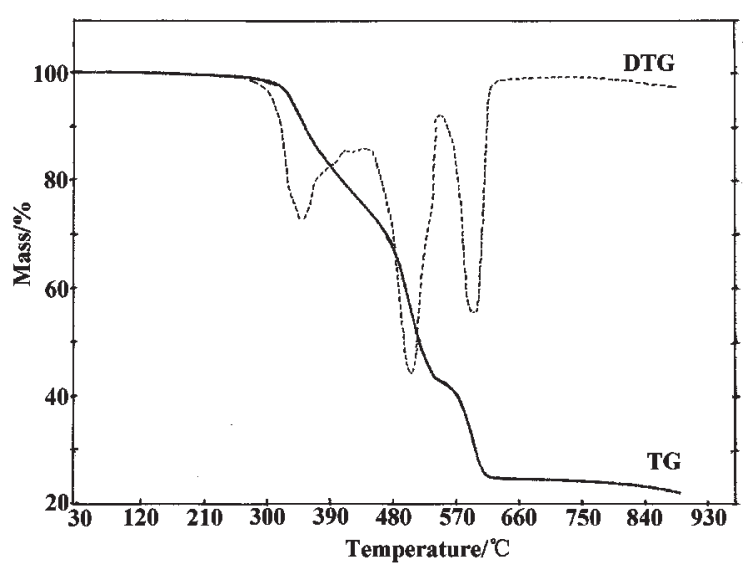

Figure 2. TG-DTG curves of $\left[\operatorname{Sm}(o-\mathrm{ClBA})_{3} \mathrm{phen}\right]_{2}\left(\beta=5^{\circ} \mathrm{C} \mathrm{min}{ }^{-1}\right)$.

Kinetic parameters of $\left[\mathrm{Sm}(\mathrm{O}-\mathrm{ClBA})_{3} \text { phen }\right]_{2}$

The kinetic parameters for the first-step thermal decomposition of $\left[\mathrm{Sm}(o-\mathrm{ClBA})_{3} \text { phen }\right]_{2}$ could be determined by using Kissinger's method ${ }^{16}$ and Ozawa- 
Doyle's method. ${ }^{17,18}$ The calculated results are listed in Table 3, which are consistent with each other.

Therefore, the Arrhenius equation can be expressed with the average of $E$ and $\ln A$ for the first-step decomposition as follows: $\ln k=39.26-229.1 \times 10^{3} / R T$.

\section{Lifetime}

The general lifetime formula of materials is, ${ }^{10}$

$\ln \tau=a+b / T$

where $\tau$ is the lifetime at temperature $T(\mathrm{~K}), a$ and $b$ are constants. In this paper, the mass-loss of $10 \%$ lifetime was measured by isothermal temperature TG at 563.15 , 573.15, 583.15 and $593.15 \mathrm{~K}$ and listed in Table 4. By substituting the values in Table 4 into equation (1), the constants $a, b$ and linear correlation coefficients $r$ were obtained by the linear least squares method. The lifetime equation is $\ln \tau=-26.8166+20319.94 / T$. Linear correlation coefficient $r$ is 0.9967 .

\section{Experimental}

\section{Materials}

All reagents used were Analar grade and were used without further purification.

\section{Preparation of complex $\left[\mathrm{Sm}(\mathrm{o}-\mathrm{ClBA})_{3} \text { phen }\right]_{2}$}

$\mathrm{SmCl}_{3} \cdot 6 \mathrm{H}_{2} \mathrm{O}$ was obtained from the reaction of $\mathrm{Sm}_{2} \mathrm{O}_{3}$ (99.95\%) and $\mathrm{HCl}\left(6.0 \mathrm{~mol} \mathrm{~L}^{-1}\right)$. A stoichiometric amount of $o$-chlorobenzoic acid and a quantitative amount 1,10phenanthroline were mixed and then dissolved in 95\% ethanol solution. The $\mathrm{pH}$ value of the mixture was adjusted to 6-7 by adding $1.0 \mathrm{~mol} \mathrm{~L}^{-1} \mathrm{NaOH}$ solution, and then added dropwise to the ethanolic $\mathrm{SmCl}_{3}$ solution, while a

Table 3. Kinetic parameters for first-step thermal decomposition of [ $\operatorname{Sm}(o-$ (lBA) ${ }_{3}$ phen $]_{2}$

\begin{tabular}{lcccc}
\hline Method & $E /\left(\mathrm{kJ} \mathrm{mol}^{-1}\right)$ & $\bar{E} /\left(\mathrm{kJ} \mathrm{mol}^{-1}\right)$ & $\ln A$ & $\mathrm{r}$ \\
\hline Kissinger & 229.80 & 229.1 & 39.26 & 0.9995 \\
Ozawa-Doyle & 228.40 & & - & 0.9995 \\
\hline
\end{tabular}

Table 4. The lifetime of the complex $\left[\mathrm{Sm}(o-\mathrm{ClBA})_{3} \text { phen }\right]_{2}$ by isothermal temperature TG

\begin{tabular}{llll}
\hline$T /(\mathrm{K})$ & $\tau_{10 \%} /(\min )$ & $T /(\mathrm{K})$ & $\tau_{10 \%} /(\min )$ \\
\hline 563.15 & 183.41 & 583.15 & 47.19 \\
573.15 & 91.87 & 593.15 & 30.22 \\
\hline
\end{tabular}

white precipitate formed. The solution mixture was stirred for $8 \mathrm{~h}$ at room temperature and then deposited for a day. The precipitate was filtered out and washed with deionized water and 95\% ethanol. Yield: $89 \%$. Colorless cubic crystals for X-ray diffraction analysis were obtained by the slow evaporation of the filtrate. IR $(\mathrm{KBr}) \mathrm{v}_{\max } / \mathrm{cm}^{-1}$ : $1646,1617,1591,1545,1519,1477,1403,1350 \mathrm{~cm}^{-1}$. Anal. Calc. for $\mathrm{C}_{66} \mathrm{H}_{40} \mathrm{Cl}_{6} \mathrm{~N}_{4} \mathrm{O}_{12} \mathrm{Sm}_{2}$ : C, 49.66; H, 2.88; N, 3.51; Sm, 18.86; found C, 49.53; H, 2.36; N, 4.06; Sm, 18.81 .

\section{Experimental equipment and conditions}

Elemental analysis was performed on a Carlo-Erba model 1106 elemental analyzer. The content of samarium was assayed using EDTA titration method. Infrared spectra were recorded over the range $4000-400 \mathrm{~cm}^{-1}$ using BioRad FTS-135 spectrometer ( $\mathrm{KBr}$ discs). X-ray diffraction data collection for a crystal with dimension $0.38 \times 0.30 \times$ $0.22 \mathrm{~mm}$ was performed on Bruker Apex IICCD diffractometer with graphite-monochromated Mo K $\alpha$ radiation ( $\lambda=0.71073 \AA)$ at $293 \mathrm{~K}$, using $\Phi$ - $\omega$ scan mode. A semi-empirical absorption correction based on SADABS was applied. 10701 Unique data $\left(\mathrm{R}_{\mathrm{int}}=0.0172\right)$ were used to solve the structure by direct methods using SHELXS97 program, and refined on $\mathrm{F}^{2}$ by full-matrix least squares methods using SHELXL-97 program. All non-H atoms were refined anisotropically, and the $\mathrm{H}$ atoms were included in the structure-factor calculations. The crystal data and refinement details of the complex are summarized in Table 1. The TG and DTG experiments for the title compound were determined using a Perkin-Elmer's TGA7 Thermogravimetric analyzer under a nitrogen atmosphere, at a flow rate of $25 \mathrm{~mL} \mathrm{~min}^{-1}$. The heating rate used was 3,5 and $7{ }^{\circ} \mathrm{C} \mathrm{min}^{-1}$ from ambient to $925^{\circ} \mathrm{C}$, respectively. The sample weight was $2.6 \pm 0.2 \mathrm{mg}$.

\section{Conclusions}

The title complex $\left[\mathrm{Sm}(o-\mathrm{ClBA})_{3} \text { phen }\right]_{2}$ were successfully synthesized in ethanol solution. Its crystal structure was determined by single crystal X-ray diffraction. The results show that the coordination number is nine and the coordination behavior of carboxylate groups with $\mathrm{Sm}^{3+}$ ion appears to three different coordination modes. Thermal decomposition mechanism of the complex was proposed. The values of $E$ and $\ln A$ for the first-step thermal decomposition were also determined. The Arrhenius equation can be expressed as $\ln k=39.26-229.1 \times 10^{3} / R T$. The lifetime equation at mass-loss of $10 \%$ was deduced as $\ln \tau=$ $-26.8166+20319.94 / T$. 


\section{Acknowledgments}

This project was supported by the Natural Science Foundation of Hebei Province and Hebei Education Department and Hebei Normal University.

\section{Supplementary Information}

Crystallographic data (excluding structure factors) for the structures in this paper have been deposited with the Cambridge Crystallographic Data Centre as supplementary publication no. CCDC 289363. Copies of the data can be obtained, free of charge via www.ccdc.cam.ac.uk/ conts/retrieving.html (or from the Cambridge Crystallographic Data Centre, CCDC, 12 Union Road, Cambridge CB2 1EZ, UK; fax: +44 1223 336033; or email: deposit@ccdc.cam.ac.uk).

\section{References}

1. Huang, C. H.; Coordination Chemistry of Rare Earths, Science press: Beijing, 1997, pp. 378-387 (in Chinese).

2. Li, X.; Zou, Y. Q.; Z. Kristallogr. - New Cryst. Struct. 2004, $219,419$.

3. Wang, R. F.; Wang, M. Z.; Jin, L. P.; Cai, G. L.; J. Beijing Normal Univ. (Nat. Sci. Ed.), (in Chinese). 1994, 30, 241.

4. Wang, R. F.; Wang, S. P.; Shi, S. K.; Zhang, J. J.; Rare Met. 2004, 23, 103.

5. Wang, R. F.; Wang, S. P.; Shi, S. K.; Zhang,J. J.; J. Coord. Chem. 2002, 55, 215.
6. Wang, R. F.; Wang, S. P.; Zhang, J. J.; J. Mol. Struct. 2003, 648, 151.

7. Wang, R. F.; Li, L. S.; Jin, L. P.; J. Rare Earths 1998, 16, 149.

8. Wang, R. F.; Jin, L. P.; Li, L. S.; Zu, L. S.; Zhang, J. H.; J. Coord. Chem. 1999, 47, 279.

9. Wang, R. F.; Wang, S. P.; Shi, S. K.; Zhang, J. J.; Chin. J. Struct. Chem. 2004, 23, 1300.

10. Zhang, J. J.; Wang, R. F.; Wang, S. P.; Liu, H. M.; Li, J. B.; Bai, J. H.; Ren, N.; J. Therm. Anal. Calorim., 2005, 79,181.

11. Zhang, J. J.; Wang, R. F.; Liu, H. M.; Li, J. B.; Ren, N.; Gao, Z. H.; Chin. J. Chem. 2005, 23, 646.

12. Zhang, J. J.; Wang, R. F.; Li, J. B.; Liu, H. M.; J. Therm. Anal. Calorim. 2001, 65, 241.

13. Ren, N.; Zhang, J. J.; Xu, S. L.; Wang, R. F.; Wang, S. P.; Thermochim. Acta 2005, 438, 172.

14. Ren, N.; Zhang, J. J.; Wang, R. F.; Wang, S. P.; J. Chin. Chem. Soc. 2006, 53, 293.

15. Zhang, J. J.; Wang, R. F.; Wang, S. P.; Liu, H. M.; Li, J. B.; B, J. H.; J. Therm. Anal. Calorim. 2003, 73, 977.

16. Kissinger, H. E.; Anal. Chem. 1957, 29, 1702.

17. Ozawa, T.; Bull. Chem. Soc. Jpn. 1965, 38, 1881.

18. Doyle, C. D. J.; J. Appl. Polym. Sci. 1961, 5, 285.

19. Wang, Z. L.; Jin, Z. S.; Niu, C. J.; Ni, J. Z.; J. Rare Earths 1992, 10, 102.

20. Bai, G. Z.; Chen, G. D.; Wang, Z. M. Yuan, L.; Kang, J. W.; Gao, J. Z.; Chin. J. Inorg. Chem. 1988, 4, 32.

21. Lam, A. W-H.; Wang, W. T.; Gao, S.; Wen, G. H.; Zhang, X. X.; Eur. J. Inorg. Chem. 2003, 149.

Received: December 12, 2005 Published on the web: September 26, 2006 